\title{
Adverse Externalities: Impact of the Jatibaru Raya Road Closure Policy on Third Parties
}

\author{
Angga Sukmara Christian Permadi ${ }^{1}$ \\ Ministry of National Development Planning/Bappenas - Indonesia \\ Sri Budi Eko Wardani² \\ University of Indonesia - Indonesia
}

\begin{abstract}
In his 100 days of leadership, Governor Anies issued a policy of closing one of the roads for the street vendor selling area (PKL), which led to pros and cons. The Jatibaru Raya road closure policy is seen as a step towards the realization of Anies campaign promise to establish 200,000 UMKM during the DKI Jakarta Election in 2017. Deeply examined by the externality model of neoclassical economics, the third party who is disadvantaged from the road closure policy is Block $\mathrm{G}$ traders, pedestrians, and city transport drivers. These problems are examined using the externality model of the neo-classical economic theory. The externality model is a model that views the impact (of transactions) of a third party (who does not participate in a transaction) in an agreement made between the first party and the second party. This research is about to answer the reasons why Governor Anies issued a policy on managing the Blok G Tanah Abang Market by closing one of the Jatibaru Raya Road segments and who benefited from the management policy of the Blok G Tanah Abang Market and which parties were disadvantaged for the implementation of the policy. In establishing the policy, Governor Anies reasoned to accommodate the street vendors so that the disadvantaged parties emerged from the policy so that Governor Anies was deemed to have mal-administrated the Ombudsman, one of which was by violating Law No. 22 of 2009 concerning Road Traffic and Transportation.
\end{abstract}

Keywords: Externalities; street vendor (PKL); Third Parties.

\footnotetext{
${ }^{1}$ Angga Sukmara Christian Permadi is a staff of Flood Management in Selected River Basin (FMSRB), Directorate of Water Resources and Irrigation, Ministry of National Development Planning, Jakarta, Indonesia. Email: anggasukmara08@gmail.com

${ }^{2}$ Sri Budi Eko Wardani is a lecturer of Departement of Political Science, University of Indonesia, Depok, Indonesia.
} 


\title{
Adverse Externalities: Impact of the Jatibaru Raya Road Closure Policy on Third Parties
}

\author{
Angga Sukmara Christian Permadi and Sri Budi Eko Wardani
}

\section{Introduction}

One of the interesting problems in each governor turnover in the DKI (Special Capital Region) Province of Jakarta is regarding the management of the Tanah Abang Market Area. The Tanah Abang area is a concern in each period of the Governor of DKI Jakarta because Tanah Abang has two fundamental reasons which are always discussed in each governor's period: (1) The Tanah Abang Market Area is one of the main points of congestion in DKI Jakarta and; (2) The Tanah Abang Market area is also the largest wholesale market in Southeast Asia which is the livelihood of tens of thousands of traders. The complexity of the management of Tanah Abang has led to various policies from the government era of each governor in office. In the reform era, namely from the period of Governor Fauzi Bowo (Foke), Joko Widodo (Jokowi), Basuki Tjahaja Purnama (Ahok), Djarot Saiful Hidayat, to Anies Baswedan.

More specifically, the arrangement of Tanah Abang in Block G. The arrangement of traders in Block $G$ has begun since the administration of Governor Jokowi which continued in the Governor Basuki period. The overall demolition of Block $G$ has long been planned because the Block is fairly quiet so that the income of traders is also very minimal. This can cause traders to return to become street vendors (PKL) in the Tanah Abang road area which can become a new problem in the management and arrangement of Tanah Abang. One reason for Block $G$ is quiet is the lack of parking available in the area around Block G (Kompas, 01/15/2018). Available parking spaces can only be used for two-wheeled vehicles. This resulted in congestion because there were quite a number of traders carrying their merchandise by car. The management of the Tanah Abang Market again became a major issue during the period of Anies Baswedan (who was elected as the Governor of DKI from the results of the 2017 Regional Election). Governor Anies policy in managing the Tanah Abang Market (especially Block $\mathrm{G}$ ) by providing a trading area for traders in the Jatibaru Raya road segment is a management policy for the Tanah Abang Market that is different from the previous DKI governors.

In the period of Governor Basuki, it was planned to demolish and rebuild the Block $G$ Tanah Abang Market, which had not yet been realized, apparently continued by Governor Anies, but in a different way that resulted in the loss of Third Parties from the implementation of the policies made. Judging from the existing political conditions, Governor Anies in his policies for the 
management of the Tanah Abang Market is guaranteeing political stability for his supporters which can be seen from the linkages of policies that he implemented with the promise of his campaign to cause adverse externalities for the implementation of the Jatibaru Raya road closure policy. Therefore, the question arises about the disadvantaged Third Party from the implementation of the Jatibaru Raya road closure policy by Governor Anies?

\section{Literature Review}

\subsection{Externality}

The problem regarding the closure of Jatibaru Raya Road which harms third parties is examined using an externality model that is part of political economy in a neo-classical approach, where the economy is seen as a process of someone trying to maximize fulfilment of needs based on an existing resource and this method including those institutionalized within a political institution (Caporaso and Levine, 2005: 90). In this neo-classical approach, someone who contracts in a personal capacity and someone who is involved in political action, both try to satisfy their needs to the maximum extent possible. Each of the interacting parties will definitely fight for the needs that are their goals.

The neo-classical approach begins with the idea of maximizing individual satisfaction where the next step is to use this idea to determine conditions in maximizing the welfare of individual systems that are interconnected. Welfare for a group even if on a basis must be defined differently from the basis of individual welfare. Maximum group well-being results from the maximization of welfare on the part of each member separately where the welfare of each member (individual) takes place independently, while group welfare takes on meaning when one of the two group conditions is met (Caporaso and Levine, 2005: 81). First, consumption actions affect individuals other than those who have chosen to be involved. Secondly, other people provide opportunities to increase shared prosperity through an exchange. So that from this presentation externalities can't be separated from the basis of this neo-classical approach.

An externality is a consequence of one's inability to make a property right. Rosen (1988) states that externalities occur when the activity of a single entity influences the welfare of other entities that occur outside the market mechanism (non-market mechanism). Departing from the understanding of Rhoads (1985: 113) externalities themselves are impacts (from transactions) on third parties (who do not participate in transactions) that do not pass through the price system and appear as unintentional side effects from the activities of other people or other companies or government / other institutions. In the market all transactions are private and if there are third parties involved in them, these third parties are usually rewarded or charged. 
As in the Tanah Abang management policy issues, the third parties referred to in the externality model are Angkot drivers, Block $G$ market traders or pedestrians. On the policy issues of the Tanah Abang management of public transportation drivers that usually pass Jatibaru Raya Road are required to change their routes and pedestrians since Jatibaru Raya Road is closed, then they have to walk quite far when going to Tanah Abang market from the station or vice versa. Block $G$ traders also have reduced income due to $P K L$ outside the market. Of the three, they are all third parties where they are the parties that get the impact of a policy by having a close relationship with the policy.

In the externality model, generally, all costs or capital borne by the producer are the same as those borne by the community and the profits obtained by the producer are the same as the benefits obtained by the community. Costs here are not limited to just being limited to money but can also be general, such as socio-political. In this way, simply, the government representing the community feels that a policy that is implemented is in accordance with what is needed by the community. Departing from the presentation of Kolm quoted by DJ. A. Simamarta (1994: 58-59), the externality of one person to another occurs when the decision of the person (party) first with the person (party) second concerning the person (party) third without the approval of the person (third party). In other words, the externality will arise if it fulfils two (2) conditions:

1. The effect of action;

2. There is no compensation for the influence.

In overcoming externalities, if an implementation of the concept of externality is violated, the party that has more authority in an existing transaction can give sanctions to third parties who are outside the transaction. If the party that has the authority in the transaction is one of them is the government, then the government can overcome it by giving sanctions in the form of fines or rewards in the form of subsidies through prices. In addition, the government can also act on third parties by applying regulations to the government by applying standards and threats of punishment. Simply put, there is a binding ban on regulation or policy that is made. The government can also implement a court system, in other words, the disadvantaged parties can sue the court. In Externalities, no one has a level of satisfaction with the wishes of the party concerned because it is influenced by a contract that he does not voluntarily enter. The term "externality" refers to a series of effects of transactions on people who are not parties to the transaction (Caporaso and Levine, 2008: 90). If transactions have such effects, they do not always improve welfare. If not, the market has failed to achieve its objectives, and in addition to the market method, it must be introduced to meet the end of maximizing the satisfaction of personal desires. 
There are special problems in neo-classical theory where one can argue from the point of view of social justice, that specifically with the existence of an externality model, people are asked to pay or benefit from certain conditions or policies that they do not have or in words others they do not have authority and power in existing conditions or policies (Caporaso and Levine, 2005: 90). They are given gifts or punishments on the basis that are not relevant to their own performance. While this argument has some appeal, the reasons for neoclassical economics on a different basis: namely efficient economic operations. Exposure to Mansfield (1982: 453) regarding externalities is explained more vigorously, he argues that the pattern of resource allocation is distorted when externalities exist as they describe it as follows: If a person takes action that contributes to the welfare of the community but which does not have an impact on the community, he is likely to take such action less frequently than socially optimal actions.

Mansfield's explanation or understanding above is a neo-classical understanding that is so intense that someone who has power can influence parties outside the agreement or policy made and this is a fundamental tendency of externality. For neoclassical thinkers, the idea of a series of activities in which economic agents involve others unconsciously opens the door to politics, in the political sense of a state's actions (Mansfield, 1982). Based on Mansfield's understanding of Caporaso and Levine (2005: 92) draw it into three concepts in the neo-classical view of the case in the externality model.

First, the political process can be used to correct market shortages by bringing personnel costs and income in line with social costs and benefits. There are different policy instruments that can be used to equalize personal and social costs. One of them is fine, besides that is a subsidy. Fines are imposed on a producer which is related to externalities. Subsidies are also imposed on parties related to externalities. It is simpler if the government and financiers who make a deal then those who get fines or subsidies are third parties such as the community.

Second, controlling the externality requires government regulations. In contrast to fines and subsidies that seek to limit externalities through a system of prices or tariffs, regulations seek control through standards that are in accordance with the rules that can be legally enforced. In other words, regulations involve authoritative prohibitions and demands. Regulations may concern the behaviour of a determination, including the stipulation of permissible prices for monopolies, bidding standards for the arms industry, safety standards for airlines, legal pollution limits for polluting companies, rules for toxic waste disposal and also economic and public road management under the authority of the government. 
Third, the government's response to externalities is by providing a justice system. Instead of government regulations, fines, or subsidies, the aggrieved party may file a lawsuit and bring the accused party to court. In this concept, Stiglitz (1988: 233) shows that in the mechanism at work, property rights must be well defined. Judicial actions will not succeed if the resources used are the same. In addition, transaction costs for those who mobilize to bring legal action (the injured party) can be very high and subject to the same problems of collective action as those for public goods. Only the cost of information is related to determining who is injured or who is harmed and how much it is, maybe the costs incurred are too expensive. And the cost of legal action for one person may be very high compared to the benefits, while for a group the costs incurred may far outweigh the benefits.

\subsection{Previous Studies}

The literature review of this study uses the work of James A. Caporaso and David P. Levine entitled Theories of Political Economy published by Cambridge University Press in 2005 in New York. In the work of James A. Caporaso and David P. Levine, this specifically discusses the political economy. This work explains in detail about the concepts, methods, models, and political economy correlations in a case or problem. This Political Economy by James A. Caporaso and David P. Levine is specifically and deeply explained about the neo-classical approach in political economy, especially in the model of externalities. From the existing understanding, it can make the foundation material for thinking the writer in dissecting the problems of the management of Tanah Abang.

The work of James A. Caporaso and David P. Levine has deficiencies in the theoretical correlations he describes. James A. Caporaso and David P. Levine emphasize political economy more on neo-classical approaches including the externality model to problems or cases that exist in Western countries. From these shortcomings, the gap is found to be completed by the author with a new correlation problem, namely the management of Tanah Abang Market, Indonesia. Not only culturally and socio-politically, even economically Indonesia problems differ from those of the West. This externality model of James A. Caporaso and David P. Levine will be used as analysis knives as well as tested in discussing the problems of Tanah Abang management. It is from the correlation of the different problems that make the research on the management of Tanah Abang different from the work of James A. Caporaso and David P. Levine, although using his ideas and theories.

The next literature review used was the thesis research of the University of Indonesia's Faculty of Economics's planning and public policy master program, Santi Agustina, "Evaluasi Formula Alokasi Dana Desa Di Kabupaten Pemalang Tahun 2011'. This thesis describes the implementation of the village 
government based on Laws No. 32 of 2004 and PP No. 72 of 2005 concerning Villages which are formal juridical grounds which state that villages are autonomous regions. As a consequence, the village received transfer funds from the government on it as part of the principle of "money follow function" known as Village Fund Allocation (ADD). The disadvantage of this study is about political economic factors that play and have a significant role in allocating funds in policy, wherein this study the influence of political economy is less discussed.

From the shortcomings in Santi Agustina's research on "Evaluating the Village Fund Allocation Formula in Pemalang Regency in 2011", a gap can be found in future studies to complement the results of this study to determine the extent to which an economic and regulatory factor influences a policy politically. In the research that will be studied on the management problems of Tanah Abang Market, policy correlation with several factors that influence it will be discussed in depth so that policies that are related to public policy and the economy and regulation are raised. This is what distinguishes the research that will be done by the author with the thesis used as a literature review.

\section{Methodology}

Externalities that are detrimental to third parties, namely the efficiency of Block $G$ traders, pedestrians, and city transportation drivers are assessed using qualitative methods. Qualitative methods are methods that make observations through wide lenses, looking for patterns between relationships between previously unspecified concepts (Brannen, 2005: 11). In qualitative research, the literature is consistently used based on assumptions derived from the participants (Creswell, 2010: 20). Qualitative methods basically analyze, collect, classify, and interpret facts and the relationship between the facts of nature, society, human behaviour in order to find the principles of knowledge and new methods in an effort to respond to the situation or social reality that occurs.

\section{Result, Analysis, and Discussions}

\subsection{Externalities of Block $G$ Traders, Pedestrians, and City Transport Drivers}

Governor Anies controversy policy regarding the closure of Jatibaru Raya Road has brought externalities to several parties, including Block $G$ Traders, Pedestrians, and City Transportation drivers. The three parties who experienced the externality impact of the policy were third parties outside the first and second parties who had the power to determine the policy. Departing from the understanding of Caporaso and Levine (2005), it can be understood simply that someone who makes a contract in a personal capacity and someone who is involved in political action, both try to satisfy their needs to the maximum extent possible. Each of the interacting parties will definitely fight for the needs that are their goals. However, the third party is a party that does not play a role in making 
existing policies so that the course of the policy is clearly profitable and in accordance with the objectives of the first party and the second party.

In the first and second parties externalities clearly have a goal to achieve the welfare of each member (individual) fully takes place independently, while group welfare takes on meaning when one of the two group conditions is met (Caporaso and Levine, 2005: 81). First, consumption actions affect individuals other than those who have chosen to be involved. Secondly, other people provide opportunities to increase shared prosperity through an exchange. In this case, the first party is the DKI Jakarta Provincial Government represented by Governor Anies and the second party is the Tanah Abang community and also the Tanah Abang community leader represented by Haji Lulung. From this explanation, there is an agreement or contract that is formulated and implemented in the Jatibaru Raya Road closure policy that expresses and accommodates the interests of both parties. Meanwhile, third parties, namely: Block G Traders, Pedestrians and Public Transportation Drivers, are parties who do not have the power and role in the formulation to the implementation of these policies so that they are the most affected parties of the existing policies.

\subsubsection{Block $\mathrm{G}$ trader}

The externalities experienced by Block $\mathrm{G}$ Traders are the most important to consider. It is different from pedestrians and city transport drivers who experience externalities by being able to change routes or the usual road directions. Meanwhile, Block G Traders are still having a long debate about the relocation of traders on the grounds of the DKI Jakarta Provincial Government that the market will be rejuvenated. The policy that is considered economic policy by setting up 400 tents for PKL by closing one of the Jatibaru Raya Road segments has led to externalities for traders selling inside the Tanah Abang Block G. Market Governor Anies policy has made Block G traders scream. They are traders who are in the market and rent kiosks (Widjaja, 2017)

Block $G$ traders themselves are traders who provide retribution for the DKI Jakarta Provincial Government, while PKL are not but Block G traders are considered children when the policy is set by Governor Anies by closing Jatibaru Raya Road. The transfer of functions of public facilities, especially highways as selling areas is very far from the basis of their use as public facilities for public transportation. The place to sell should be on the market, not on the highway. Basically, the market is a public place where supplies and other objects are exposed for sale; but the word has been generalized so that everyone in an intimate business relationship and conducting extensive transactions in any commodity is also included in the market section (Jevons, 1965: 84). To be interesting is that in the closure policy of Jatibaru Road, the closed road is located right in front of the Block $G$ Market which used to be a trading centre in the area. 
Block $G$ trader Yeni (52) said he was confused about the fate of the traders in the official kiosks inside the Tanah Abang market blocks (Widjaja, 2017). The Governor of Anies policy to close Jatibaru Raya Road has immediately turned off the income of traders in the Tanah Abang Market blocks slowly. Governor Anies reasoned that what he did was to accommodate the interests of all parties. Including the interests of street vendors/PKL (Widjaja, 2017). The policy made by the Governor of Anies caused a lot of disappointment for traders who were selling inside the Tanah Abang Market blocks. In this study, the previous discussion has also been discussed about indications of the stipulation of the policy.

The policy of closing Jatibaru Raya Road which is a political economy policy that is strongly indicated to be related to political contracts during the Governor of Anies campaign so that it is implemented by closing part of the road by providing tents for PKL has caused externalities for traders in Tanah Abang Block G. Market. Referring to Rhoads understanding (1985: 113) externality itself is an impact (of transactions) on third parties (who do not participate in transactions) so that third parties must follow the existing policy flow. As part of the third party Yeni also stated that she was very disappointed because she felt that Governor Anies preferred to organize PKL rather than responding to the willingness of traders of Block $G$ (Widjaja, 2017). This statement is clearly a fundamental complaint from the parties who experienced the impact of externalities because they did not have the strength and contribution in the policy.

Issues such as the Jatibaru Raya Road policy are actually commonplace in a big city, where economic problems are a wrapper of political goals by regional heads and influential individuals. Jevons (1965: 84) explains that a large city may have many markets because there are important trade branches, and by some market heads this market may not be localized. The absence of this market localization made the PKL also spread. Actually, the control carried out during Governor Jokowi's time and Governor Basuki in order to control was very good, which proved that the traffic in Tanah Abang had been smooth when it was cleared off the PKL. Aji explained that;

"The period of Governor Jokowi to Governor Basuki in managing Tanah Abang was good but now the PKL who are already on the streets become a new problem and are actually sorry for seeing the condition of the Block $G$ traders, especially on the 3rd and 4th floor. they are back on the streets as forced PKL, "(Aji, 2018).

PKL relocation can actually be done by relocating them to the market or in one area so that they do not sell on the road. However, the Governor of Anies actually closed Jatibaru Raya Road by providing tents for PKL to sell. In addition to Yeni, another trader, Taufik, a Block $\mathrm{G}$ trader who also has complaints 
"If the PKL are inaugurated, the merchants of sellers in stores or kiosks in Block G will automatically be quiet" (Widjaja, 2017). This concern is very reasonable because buyers will find it easier to buy on the roadside rather than enter the market because the items sought are already available on the streets so there is no need to go up and down the market to find or buy goods. Overcoming the third party in the economic externality clearly needs a way out so as not to create increasingly violent protests from traders in the market because their income is indirectly seized by PKL supported by the government.

Taufik added, "with the inauguration of the PKL, Block G Traders' income is quieter, traders become confused, and also become chaotic because access to Block $G$ becomes difficult" (Widjaja, 2017). If Block G Traders externalities in the Jatibaru Raya Road closure policy are allowed, besides the market becomes quiet, traders can also be unemployed or even take to the streets to become PKL as well so that it will add to severe congestion in Tanah Abang. If so, if it is prohibited it will definitely be chaotic because it is related to the income of traders to find food. Directly, Block G Traders are greatly disadvantaged by the policy. Economic competition cannot be avoided between Block $G$ Traders and PKL so that many Block $G$ traders on the 3rd and 4th floors of Block $G$ are trading on the streets so as not to lose their income.

Traders who take to the streets do not necessarily leave their kiosks inside Block G Market, so the kiosks are used as warehouses or investments for traders. Such conditions eventually lead to problems with PD Pasar Jaya as the manager of the Tanah Abang Market. The naughty trader in Block $G$ will be disciplined with the cancellation of his contract and there are already around 2,200 traders and some of them have been cancelled by PD. Pasar Jaya because kiosks are not for investment but for selling (Sunarto, 2018). The actions of the traders in Block $G$ are actually natural in the context of instincts for survival. Traders will always be looking for profit, as well as the Block G. Traders. They deliberately make their kiosks an investment for storing goods for sale on the streets.

In Block $G$ the 'original traders' ${ }^{3}$ are on the ground floor, which is a trader selling groceries, those who go down selling to become PKL again are traders who sell textiles and food that used to sell on the roadside (Sunarto, 2018). From PD Pasar Jaya's perspective, the actions of traders who take to the streets are a violation and must be subject to sanctions so that the traders deter and do not repeat such things (not returning to the streets). Basically, PD Pasar Jaya only carries out established regulations and this is the problem for third parties in the externality of the closure policy of Jatibaru Raya Road.

\footnotetext{
${ }^{3}$ Traders who stay longer or sell in Block G occupy the 1st and 2nd floors, while traders selling on the 3rd and 4th floors are PKL who have been relocated by Governor Jokowi into Block $\mathrm{G}$ so as not to cause congestion.
} 
The traders who were initially PKL then relocated to the Block $G$ market by Governor Jokowi because they were forced to return to the streets to trade because their kiosks in the market were empty of buyers due to PKL selling on the street in front of the market. Those who do this are seen as naughty traders. One example of a rogue trader is an investment kiosk that is made into a warehouse, but he still sells as a PKL and that is what is regulated by PD Pasar Jaya (Sunarto, 2018). However, Block G traders, especially those who inhabit the 3rd and 4th floors, have no other choice but to take to the streets again to become PKL and compete with the PKL facilitated by the DKI Provincial Government. As a third party in this classical economic externality model, Block $\mathrm{G}$ Traders clearly face two choices. First, survive in Block $G$ but the turnover of merchandise is decreasing day by day. Second, taking to the streets competing with PKL with the risk of getting sanctions from PD Pasar Jaya in the form of sealing kiosks.

The heavy choice must indeed be taken by the Block $G$ trader, this has entered the market mechanism of the National Bank and the competition tends to be very free. Open competition between Block G traders and PKL supported by the DKI Jakarta Provincial Government essentially made Block G traders go back to the streets. Caporaso and Levine (2008) emphasize that in externalities the assumption that everyone knows about what they want leads naturally to the theorem which states the optimality of free markets. It is natural that from the externality model, Block $G$ traders as third parties are very affected by the closing policy of Raya Jatibaru Road and they tend to be harmed because they have to compete freely with PKL without the support of the government. Supposedly those who get support from the government are Block $G$ traders because they are traders who help DKI Jakarta PAD (Regional Revenue) by providing routine retribution through PD Pasar Jaya.

\subsubsection{Pedestrians}

In the externality model, the third party outside the first party and the second party that makes a decision or policy is very dependent on the implementation of a decision or policy made by the first and second parties. Third parties do not have the share and strength in decisions or policies made by the first party and the second party. This makes third parties in the concept of externality not only experienced by Block $\mathrm{G}$ traders but also experienced by pedestrians. Pedestrians are also very influential from the closing policy of Jatibaru Raya Road because the road is at the entrance and exit of train passengers at Tanah Abang Station. When the road is closed, those who are going to Tanah Abang Market are forced to walk or use Transjakarta Bus transportation provided by the DKI Jakarta Provincial Government.

Transjakarta Bus Provisioning which operates around the Tanah Abang area has turned out to be ineffective because the passengers and transportation 
facilities are not comparable. This is because the Tanah Abang station is one of the densest stations in DKI Jakarta. Tens of thousands of people move in and out using the train at Tanah Abang Station. The obstacle is that when a passenger exits Tanah Abang Station and the transportation facilities used are Transjakarta Buses, there will be a buildup of prospective Transjakarta Bus passengers. Whereas only one road that can be traversed by public transportation is reserved for Transjakarta Buses so that other public transportation cannot pass through so that they are changed by the DKI Jakarta Provincial Government. This makes many of the train passengers who leave the Tanah Abang Station choose to walk so that it adds to the density and congestion in the Tanah Abang area.

The hardship of pedestrians walking on Jatibaru Raya Road was actually rather difficult because they had to be crowded due to the many PKL selling. The road that can be traversed by pedestrians after the tents on Jatibaru Raya Road is not so wide if it is traversed by pedestrians because the distance of the tents facing each other is not so wide that it is quite narrowly traversed by pedestrians. Jati Baru Raya Road is one of the worst congestion points in the Tanah Abang area at rush hour. Based on Jabodetabek's PT Commuter Line data, every Monday to Friday, there is an average of 50 thousand commuter train users who depart and disembark at Abang land station. The number only decreased to 35 thousand on Saturday and Sunday (Friana, 2017).

The problem is compounded by the many traders in the Market who also sell their wares to PKL who are their business networks, so they can sell their goods quickly to buyers who are walking or passing through the Tanah Abang area and this is what causes congestion (Sunarto, 2018). Referring to Jevons (1965: 85) understanding that the matter in the problem is due to the absence of a central point of the market intended for exchange or public trade, or also the auction room, where traders agree to meet and transact business. Block $G$ as a central market in the region indirectly has been distorted by the DKI Jakarta Provincial Government by implementing the Jatibaru Raya Road closure policy for the area of selling PKL.

The pedestrians who will shop in Block $G$ will instead prefer to shop at street vendors because the items sought are already available in PKL stalls. This is reasonable because it is faster and easier to get goods in PKL than it has to enter the Tanah Abang Block $G$ Market. If the provincial government accommodates the interests of all parties, it is appropriate that the PKL are accommodated in the market, not placing them on the streets causing congestion due to the many pedestrians through Jatibaru Raya Road and get protests from Block $G$ merchants. Besides pedestrians who have intended to shop at Block $G$ but prefer shopping at PKL, pedestrians who do not have the intention to shop often buy goods at PKL because they see the goods offered. This is what makes Jatibaru Raya Road more congested and congested. 
Examined from the concept of externalities Caporaso and Levine (2005: 90) one should be able to refute an existing decision or policy from the point of view of social justice that, specifically with the existence of an externality model, people are asked to pay or benefit from circumstances or certain policies that they do not have or in other words they do not have the authority and power in existing conditions or policies. In this case, pedestrians in Indonesia themselves are not a community that consists of various individuals who tend to be disorganized so that to oppose or refute the policy does not have strong political bargaining. It is precisely the rejection or opposition that must have strength in terms of strong political bargaining power from Block $G$ traders and City Transportation drivers because they have communities and even organizations.

It is undeniable, with the closing of the pedestrian Jatibaru Road which so far before the road was closed it was very easy to get transportation facilities with various choices. They can choose to ride the Transjakarta Bus, Ojek, Angkot (City Transportation), or bajaj. The closure of a Jatibaru Raya road section by the DKI Jakarta Provincial Government for the PKL selling area makes people who go in and out of Tanah Abang Station not have many choices of transportation facilities. The choices taken are queuing up the Transjakarta Bus, walking, or using public transportation, bajaj, or motorcycle taxi with the risk of having to go through a rotating road and require a longer time. At least those choices that eventually made people who came out or entered the Tanah Abang Station preferred to walk.

Congestion on Jatibaru Raya Road around the Block G Market area was compounded by pedestrians coming out of the sidewalk and crossing carelessly. This is because Jatibaru Raya Road is increasingly chaotic due to PKL and street vendors who walk on the sidewalks that narrow the streets of pedestrians so that pedestrians do not have a decent road to pass. If pedestrians want to use a pedestrian bridge (JPO), they have to walk about half a kilometre towards Block G Tanah Abang (Friana, 2017). Roads that are passed by pedestrians both on the sidewalk and in the JPO are not comparable to the number of pedestrians passing through Jatibaru Raya Road. Thus, pedestrians are one of the third parties in the concept of externalities affected by the agreement of the first party and the second party which gave birth to the road closure policy which did not have the power to oppose or reject the policy.

\subsubsection{City Transport Driver}

The third party externality of Governor Anies closing policy of Jatibaru Raya Road beside impacting Block $G$ Traders and pedestrians also had an impact on city transportation drivers (angkot) who had routes through Jatibaru Raya Road, Tanah Abang. City transportation drivers become one of the disadvantaged parties in the concept of externality because city transportation 
has a route that must be passed, this is what distinguishes it from bajaj or ojek. If the angkot route is changed, it will affect the revenue of angkot drivers. In the issue of the closure policy of Jatibaru Raya Road, changes in angkot routes were carried out because there were no roads that could be traversed by angkot on Jatibaru Raya Road.

Jatibaru Raya Road which is closed for the street vendors selling area automatically closes the road normally used by angkot. On the other hand, Jatibaru Raya Road is only intended for Transjakarta Buses so that angkot also cannot pass through the road. Angkot being the third party to this externality model is Mikrolet M08, people often call it M08. Mikrolet M08, a department of Tanah Abang-Kota, which is more often seen, is not taking passengers. The machines are turned off and some look empty left by the driver (Friana, 2017). This is because the route that has been changed by the DKI Jakarta Provincial Government is a route that is lonely passengers and rotates or the distance becomes too far from the existing route. The change in this route actually makes public transportation difficult because, besides public transportation, other public transportation such as bajaj or ojek will definitely prefer to pass through small streets or alleys to shorten the time or cut the road due to the Jatibaru Raya road normally covered by the Provincial Government DKI Jakarta.

The closure of Jatibaru Raya Road in front of Block G, which was previously crowded by public transportation, especially city transportation (angkot), which had many passengers after disembarking from Tanah Abang station, now had to be changed due to the closed Jatibaru Raya Road. Now the traffic jam is getting worse because the roads that are traversed by various public transportation are closed for the selling area. Irwandi, who is the Head of the DKI Jakarta Cooperative, Micro, Small and Medium Enterprises (KUMKM) Office, said the tents made traders easy to find and if buyers wanted to buy more at the same merchant, they just remembered the number of their tents (Kompas, 08/06/2018). Regarding this, Tanah Abang is also increasingly attracting buyers outside Jakarta, for example from Bekasi, Depok, Tangerang, and Bogor. This should also be considered because it will increase congestion. The exact solution is not to close the highway as a place to sell but to relocate the street vendors to the proper place of trade (by entering the Tanah Abang Market Block).

The closure of Jatibaru Raya Road along the Tanah Abang Station through Block $\mathrm{G}$ besides affecting M08 also affected the Mikrolet M10 route (Zhacky, 2017). Both city angkot, namely M08 and M10, which usually take a lot of places and look for passengers at the door of Tanah Abang Station, are rarely found anymore. The situation and scenery around Tanah Abang Station which is close to Block $G$ and Jatibaru Raya Road has changed. On a five meter wide sidewalk that should be used specifically for pedestrians due to the policy of closing Jatibaru Raya Road, there have been many street vendors who sell 
various needs. "Ranging from clothing, children's toys, to soft drinks. Not only buying and selling transactions, loading and unloading of goods also occur on the sidewalk that runs up to the intersection of the Tanah Abang G Block "(Friana, 2017). Referring from Friana (2017, accessed September 10, 2018) that changes in Mikrolet M08 and M10 routes or routes actually harm Angkot drivers because the route they are travelling is getting farther; Mikrolet M08 no longer passes Tanah Abang station when heading to Kebon Jati Road. Before turning left in the direction of Tanah Abang Station, Mikrolet M08 must turn around under the flyover at Jatibaru Raya Road towards Abdul Muis Road. Likewise, the Mikrolet M10, which had passed through Tanah Abang Station, had to turn back under the Jati Baru Raya Road flyover and then head to Cideng Barat Road.

Even though the roads became congested this did not make people switch to modes of transportation such as angkot (mikrolet), but they mostly preferred to walk. Rosen (1988) states that externalities occur when the activity of a single entity influences the welfare of other entities that occur outside the market mechanism (non-market mechanism). Obviously, drivers of public transportation M08 and M10 are also third parties to the concept of externalities that have experienced the impact of the Jatibaru Raya Road closing policy. Although the angkot drivers had protested against the policy of Jatibaru Raya Road, they still lacked the power of the first party (DKI Jakarta Provincial Government / Governor Anies) and the second party (Tanah Abang community/community leaders) in changing a decision or policy that had been set.

There is an improvement from the closing policy of Jatibaru Raya Road so that all parties' interests are accommodated. "Governor Anies explained that the road in front of Tanah Abang Station will be closed at 8:00 a.m. to 6:00 p.m. where one road segment will be closed so those street vendors (PKL) are free to sell. Roads closed for street vendors selling are those that lead to Tanah Abang Market" (Sari, 2017). Even though the PKL close at 6:00 p.m. actually do not make the loss of third parties can be overcome, especially public transportation drivers. This is because after 6:00 p.m. at work time, there are very few prospective passengers. Tanah Abang is known to be crowded when at rush hour. Even so, the angkot driver could not do anything but protest against Governor Anies policy.

\subsection{Analysis of Adverse Externalities}

Third parties who are parties outside the parties that have the power in the agreement (political contract) that gave birth to the Jatibaru Raya Road closing policy are those who do not have the authority or power in the policy. There are three important aspects in the third party that are strongly influenced by the policy, namely the Block $G$ traders, pedestrians, and angkot drivers because all three are very closely related parties in the implementation of the policy. As a third party in the externality model, Block $G$ traders, pedestrians, and 
angkot drivers are not given much choice in determining their attitude, passing them has been regulated directly or indirectly to follow the flow of agreements made by the first and second parties in the Jatibaru Road closing policy Kingdom.

Referring to the understanding of Caporaso and Levine (2005: 90), basically, the externality model is part of the political economy in a neo-classical approach, where economics is seen as a process of someone trying to maximize fulfilment of needs based on an existing resource and this method including those institutionalized within a political institution. Following the understanding of Caporaso and Levine, the closure policy of Jatibaru Raya Road which was implemented by Governor Anies (DKI Jakarta Provincial Government) was stated to accommodate all parties by exploring the economic potential around the Block G Market area. Therefore, Jatibaru Raya's closing policy intended for PKL to sell. Although based on the reason the DKI Provincial Government accommodates the interests of all parties, it indirectly affects the economy in Jakarta, especially in Tanah Abang.

From the implementation of the policy, the parties that are closely related are Block $G$ traders who must compete with PKL in seeking income. Then pedestrians, who every day tens of thousands of pedestrians pass through Jatibaru Street who have to experience difficulties in going through the road due to the lack of transportation modes and pedestrian facilities that are increasingly narrow. The last is public transportation drivers, who must follow the DKI Provincial Government regulations in changing routes or routes that have an impact on revenue for public transportation drivers. From these problems simply, the government representing the community feels that a policy that is implemented is in accordance with what is needed by the community and if the policy taken is not appropriate then it can be a wasteful job because the policy is not the solution, but instead adds new problems. Departing from Kolm's explanation, one person in another person occurs when the decision of the first person (party) with the person (party) concerning the third person (party) without the approval of the third person (third party) (DJ. A. Simamarta, 1994: 58-59), in other words, the externality will arise if it fulfils two (2) conditions:

1. The effect of action;

2. There is no compensation for the influence.

Jatibaru Raya Road Closure has fulfilled two conditions in externalities, where third parties, both Block $G$ traders, pedestrians, and angkot drivers, are the parties that have been harmed due to the policy and there is no compensation from the impact of the implementation of the policy. In overcoming externalities, if an implementation of the concept of externality is violated, the party that has more authority in an existing transaction can give 
sanctions to third parties who are outside the transaction. From this, actually, Block $G$ traders (who are third parties) are considered to have committed a violation because they left their kiosks to sell on the streets and get sanctions such as sealing kiosks because they took to the streets to sell competing with $\mathrm{PKL}$ to make a living. Although the kiosk is used as a warehouse that is considered by PD. Pasar Jaya as an investment and Block $G$ traders going down selling on the streets have made them get sanctions and they have no other choice in this matter.

Referring to Mansfield (1982) for neo-classical thinkers, the idea of a series of activities in which economic agents or a political figure (in the case of Jatibaru Road) involves others unconsciously by opening the door to politics, in the political sense of state action or government. The DKI Jakarta Provincial Government represented by Governor Anies and Haji Lulung who represented the Tanah Abang community directly or indirectly attracted Block G traders, pedestrians, and angkot drivers as third parties in the externality model and they were the losers from the Jatibaru Raya Road closing policy. Based on Mansfield's understanding of Caporaso and Levine (2005: 92) regarding these problems can be drawn into three approaches in the neo-classical view of cases in the externality model. First, the political process can be used to correct market shortages by bringing personnel costs and income in line with social costs and benefits. Second, controlling the externality requires government regulations. Third, the government's response to externalities is by providing a justice system.

Of the three Caporaso and Levine approaches in the case of the closure of Raya Jatibaru Road, the relevant approach, in that case, is the second approach. This approach is appropriate because the problems that occur with third parties must receive control from the first party and second parties that are different from fines and subsidies, by trying to limit externalities through a price system or tariffs for merchandise sold between street vendors and Block $G$ traders. regulations to seek control through standard setting that is in accordance with the rules that can be legally enforced. In other words, the regulations stipulated by the DKI Jakarta Provincial Government involve prohibitions and authoritative demands. This is experienced by Block G Traders and public transportation drivers so that it is very detrimental to them.

The existing regulations also concern the management of economic centres and public roads under the authority of the government. It is from this regulation that pedestrians are greatly disadvantaged because the road closure rules used for land selling street vendors make the road traversed by pedestrians narrower. Rhoads (1985: 113) also explained that externalities appear as unintentional side effects from the activities of other people or other companies or also government/institutions. The in-depth study is very important in the case or problem of closure of Jatibaru Raya Road so that the third party does not 
suffer too long and its interests can also be accommodated, if referring to the reason of Governor Anies who has answered the problem of closing Jatibaru Raya Road is to accommodate the interests of all parties.

It can be understood simply that after being released from the autocracy period and entering the reform era, with the election in various regions, the election is only a way to gain power. This can be seen from the problems of the road closure policy, both Governor Anies, Haji Lulung and the Tanah Abang community as well as third parties from externalities (Block $G$ Traders, pedestrians, and angkot drivers) the closing policy of Jatibaru Raya Road is actually just Homo Economicus rational beings who pursue their interests and are able to make decisions for their subjective goals and also as Homo Democritus who only become political beings who participate in political life together (Hardiman, 2013: 13). The enactment of the road closure policy is an indication of the implementation of a political contract between the elected Governor and local authorities in Tanah Abang, which gave rise to third parties who were greatly disadvantaged by the implementation of the policy.

The enactment of the Jatibaru Raya Road closure policy as a street vendor by Governor Anies has made him enter the examination of the Ombudsman of the Republic of Indonesia. The Ombudsman of the Republic of Indonesia, commonly known as the ORI or the Ombudsman, is a body that handles public service issues in Indonesia. In the case of Tanah Abang management, especially Block $G$, based on reports from the public regarding the closure policy of Jatibaru Raya Road, it has dragged Governor Anies into the issue of public services which could lead to the termination of the elected Governor of Jakarta. The problem of road closure policies and management of Block $G$ is very thick with political elements so that it is quite difficult to resolve if there is no decisive action from an authorized body, such as the Ombudsman. Quoting Lindblom's statement that actually a problem cannot define itself (Rushefky, 1990: 4). The harshness of the problems with Block $G$ is actually not much different from Londblom's statement, where policies to solve a problem actually cause many new problems.

\section{Conclusion}

The problem of management of Tanah Abang is basically based on two things, namely regarding PKL and congestion. $\mathrm{PKL}$ are present in the Tanah Abang area because of the hectic Tanah Abang area in the process of buying and selling. This is not so surprising since the Dutch East Indies, the Tanah Abang market, which used to be the Saturday Market, was the crossing area for the entry of goods from outside Batavia. Entering the modern era, the Tanah Abang area is increasingly developing into a thriving economic area of the DKI Jakarta complex built by Bang Ali. However, the progress of the development of Tanah 
Abang has led to new problems with the presence of PKL and severe congestion in the Tanah Abang area. Therefore, since the leadership of Bang Yos as the Governor of DKI, the PKL have begun to be disciplined but are still often returning to the streets because of information about the curbing operations that are still often leaky and not routine.

The policy adopted by Governor Anies during the transition period did not change the policy of the previous governors. Since the time of the Governor Foke that issued the DKI Jakarta Regional Regulation No. 1 of 2012 concerning the 2030 Regional Spatial Plan, the Tanah Abang area has been programmed to be arranged neatly. Based on this regulation, Governor Jokowi carried out the execution of PKL control and relocation of PKL into the Block G Tanah Abang Market and this was being done for the future of Governor Basuki and Governor Djarot. The DKI governor's policy before the governor Anies leadership period in managing Tanah Abang was to organize the Tanah Abang PKL by relocating it to the market and building sky bridges as a solution to congestion so that pedestrians did not scatter on compilation transportation from Tanah Abang Station. However, Governor Anies policy is a little different, he presents PKL on the streets but in the end, this PKL will be relocated together with Block $G$ traders and build sky bridges to unravel existing congestion. In essence, the policy issued by Governor Anies was an incremental policy, which was nothing more than the previous policy that was opposed was to relocate traders, rejuvenate the Block $G$ building, and build a sky bridge.

In implementing the Jatibaru Raya Road closure policy there were various parties who were harmed. This aggrieved party is a third party from the concept of externality. They are the affected parties of a policy or a decision made by the first party and the second party. The first decision on this agreement was the government under the leadership of Governor Anies who issued a road selection decision. Meanwhile, the second party is Haji Lulung who represent the parties representing the Tanah Abang community. Then, the aggrieved party is Block G Trader, pedestrian, Public Transportation Driver, who is the third party or affected party from a policy or decision formulated and determined by the first party and third party for the benefit of third parties (first party and second party).

\section{References}

Agustina, Santi. 2011. Evaluasi Formula Alokasi Dana Desa Di Kabupaten Pemalang Tahun 2011. Tesis. Program Magister Perencanaan dan Kebijakan Publik, Fakultas Ekonomi, Universitas Indonesia

Aji. Interview. October 29, 2018. Residents of Tanah Abang.

Brannen, Julia Brannen. 2005. Menggabungkan Pendekatan kalitatif dan Pendekatan Kuantitatif: Sebuah Tinjauan, Yogakarta: Pustaka Pelajar. 
Caporaso, James A, dan David P. Levine. 2008. Teori-teori Ekonomi Politik. Yogyakarta: Pustaka Pelajar.

Carina, Jessi. 2018. Kadis KUMKM: Tenda PKL di Jatibaru Buat Pengunjung Tanah Abang Meningkat. https://megapolitan.kompas.com/read/2018/06/08/15385301/kadiskumkm-tenda-pkl-di-jatibaru-buat-pengunjung-tanah-abangmeningkat. (accessed September 15, 2018 at 11.31 WIB)

Creswell, John W. 2010. Research Design Pendakatan Kualitatif, Kuantitatif, dan Mixed, Yogyakarta: Pustaka Pelajar.

Hardiman, F. Budi. 2013. Dalam Moncong Oligarki: Skandal Demokrasi di Indonesia. Yogyakarta: Kanisius.

Friana, Hendra. 2017. Benarkah Pejalan Kaki Penyebab Kemacetan Tanah Abang. https://tirto.id/benarkah-pejalan-kaki-penyebab-kemacetan-tanahabang-czNb (accessed September 10, 2018, at 08.48 WIB)

Jevons, William Stanley. 1965. The Theory of Political Economy. New York: Augustus M. Kelly (AMK).

Mansfield, Edwin. 1982. Micro-Economics: Theory and Applications. New York: W. W. Norton Co.

Rhoads, Steven E. 1985. The Economist's View of The World: Government, Markets, and Public Policy. UK: Cambridge University Press.

Rosen, H.S, 1988. Public Finance, second edition. Washington: Toppan Co.Ltd

Rushefky, Mark. 1990. Public Policy in The United States. Pacific Grove: Brooks / Cole Publishing Company.

Sari, Nursita. 2017. Anies Tutup Jalan di Tanah Abang untuk PKL, Ini Penjelasan Gubernur DKI Jakarta.

http://medan.tribunnews.com/2017/12/21/anies-tutup-jalan-di-tanahabang-untuk-pkl-ini-penjelasan-gubernur-dki-jakarta (accessed Juli 15, 2018, at 21.00 WIB)

Simamarta, Dj. A. 1994. Ekonomi Publik dan Eksternal: Ekonomi Tanpa Pasar. Jakarta: Lembaga Penerbit Fakultas Ekonomi Universitas Indonesia.

Stiglitz, Joseph E. 1988. Economics of the Public Sector. New York: W. W. Norton

Sunarto. Interview. June 6, 2018. Manager of PD. Pasar Jaya for the Tanah Abang area.

Purba, David Oliver. 2018. Upaya Hidupkan Pasar Block G Sejak Era Jokowi, Ahok, hingga Anies.

https://megapolitan.kompas.com/read/2018/01/15/09394421/upayahidupkan-pasar-block-g-sejak-era-jokowi-ahok-hingga-anies (accessed July 12, 2018, at 21.31 WIB)

Widjaja, Yunizafira Putri Arifin. 2017. HEADLINE: Jurus Anies Tata Tanah Abang, Siapa yang Diuntungkan?

https://www.liputan6.com/news/read/3204225/headline-jurus-aniestata-tanah-abang-siapa-yang-diuntungkan (accessed 17 September 2018 at 14.35 WIB) 
Angga Sukmara Christian Permadi and Sri Budi Eko Wardani

Zhacky, Mochamad. 2017. Jalan Depan Stasiun Tanah Abang Ditutup, Ini Perubahan Trayek Angkot.

https://news.detik.com/berita/3779867/jalan-depan-stasiun-tanahabang-ditutup-ini-perubahan-trayek-angkot (accessed September 10, 2018 at 09.12 WIB) 